\title{
Analisis Sentimen Pada Maskapai Penerbangan di Platform Twitter Menggunakan Algoritma Support Vector Machine (SVM)
}

\author{
Hendry Cipta Husada ${ }^{1 *}$, Adi Suryaputra Paramita ${ }^{2}$ \\ ${ }^{1,2}$ Program Studi Teknik Informatika, Universitas Ciputra, Surabaya, Jawa Timur \\ Email: ${ }^{1 * h e n d r y c i p t a 7 @ g m a i l . c o m, ~}{ }^{2}$ adi.suryaputra@ciputra.ac.id
}

(Naskah masuk: 15 Des 2020, direvisi: 25 Jan 2021, diterima: 27 Jan 2021)

\begin{abstract}
Abstrak
Perkembangan teknologi saat ini telah memberikan kemudahan bagi banyak orang dalam mendapatkan dan menyebarkan informasi di berbagai social media platform. Twitter merupakan salah satu media yang kerap digunakan untuk menyampaikan opini sebagai bentuk reaksi seseorang atas suatu hal. Opini yang terdapat di Twitter dapat digunakan perusahaan maskapai penerbangan sebagai parameter kunci untuk mengetahui tingkat kepuasan publik sekaligus bahan evaluasi bagi perusahaan. Berdasarkan hal tersebut, diperlukan sebuah metode yang dapat secara otomatis melakukan klasifikasi opini ke dalam kategori positif, negatif, atau netral melalui proses analisis sentimen. Proses analisis sentimen dilakukan dengan proses data preprocessing, pembobotan kata menggunakan metode TF-IDF, penerapan algoritma, dan pembahasan atas hasil klasifikasi. Klasifikasi opini dilakukan dengan machine learning approach memanfaatkan algoritma multi-class Support Vector Machine (SVM). Data yang digunakan dalam penelitian ini adalah opini dalam bahasa Inggris dari para pengguna Twitter terhadap maskapai penerbangan. Berdasarkan pengujian yang telah dilakukan, hasil klasifikasi terbaik diperoleh menggunakan SVM kernel RBF pada nilai parameter $C($ complexity $)=10$ dan $\gamma($ gamma $)=1$, dengan nilai accuracy sebesar 84,37\% dan 80,41\% ketika menggunakan 10 -fold cross validation.
\end{abstract}

Kata Kunci: Twitter, Opini, Analisis Sentimen, Maskapai Penerbangan, Machine Learning, Klasifikasi, Support Vector Machine.

\section{Sentiment Analysis of Airline on Twitter Platform Using Support Vector Machine (SVM) Algorithm}

\begin{abstract}
Current technological developments have been given an easiness to a lot of people in terms of access to and distribute information on the various social media platform. Twitter is one of the media that often used for conveying opinion as a form of a reaction over a thing. The opinions contained on Twitter can be used by airline companies as a key parameter to measure the level of public satisfaction as well as evaluation materials for the company. Therefore, required a method that can automatically do opinion classifications into positive, negative, or neutral category through the sentiment analysis process. The sentiment analysis process is carried out with the data pre-processing process, word weighting using the TF-IDF method, the implementation of the algorithm, and analysis of the classification result. The opinion classification process is carried out with a machine learning approach using the multi-class Support Vector Machine (SVM) algorithm. The data used in this research are opinions in English vocabulary from Twitter users towards airlines. Based on experiments, the best classification results are obtained using SVM's RBF kernel on the parameter value C (complexity) $=10$ and $\gamma$ (gamma) $=1$, with accuracy values $84.37 \%$ and $80.41 \%$ when using 10 -fold cross validation.
\end{abstract}

Keywords: Twitter, Opinion, Sentiment Analysis, Airline, Machine Learning, Classification, Support Vector Machine. 


\section{PENDAHULUAN}

Industri penerbangan adalah salah satu industri terbesar dan terkemuka di dunia karena memiliki peran besar terhadap kehidupan masyarakat. Salah satu negara yang memperoleh manfaat paling besar adalah Amerika yang setidaknya terdapat 23.911 penerbangan komersil dan membawa 2.246.004 penumpang pada setiap harinya [1]. Tingginya jumlah pengguna transportasi udara dikarenakan mobilitas masyarakat yang semakin meningkat dan tuntutan untuk melakukan perjalanan di dalam dan luar negeri dalam waktu yang singkat. Hal tersebut tentunya mendorong setiap perusahaan maskapai penerbangan untuk berusaha memperoleh keunggulan kompetitif dengan terus meningkatkan pelayanan mereka.

Perkembangan teknologi saat ini semakin mempermudah banyak orang dalam melontarkan opini di social media online sebagai bentuk respon dan tanggapan akan suatu hal. Dari sekian banyak social media plaform yang tersedia, Twitter menjadi salah satu yang favorit untuk digunakan. Sepanjang tahun 2018, jumlah aktif pengguna Twitter pada tiap harinya berhasil mencapai angka 126 juta atau naik 9\% dari tahun sebelumnya [2]. Twitter sendiri merupakan social media yang berjalan secara real time, memungkinkan para penggunanya membicarakan topik yang bervariasi dan mengemukakan pemikiran secara spontan [3]. Hal ini sering dimanfaatkan oleh industri-industri untuk menyebarkan dan mengumpulkan informasi di Twitter, salah satunya adalah industri penerbangan.

Opini yang diutarakan di Twitter dapat dijadikan sebagai parameter kunci untuk mengukur tingkat kepuasan publik terhadap suatu maskapai penerbangan. Informasi yang diperoleh dapat berupa pertanyaan, masukan, kritik, hingga apresiasi. Semua opini yang telah beredar tentunya dapat mempengaruhi citra dari perusahaan dan besar kemungkinan kecenderungan yang ada dalam opini tersebut dijadikan sebagai bahan evaluasi maupun alat penentu kebijakan. Maka dari itu penting bagi perusahaan untuk memberikan perhatian khusus pada hal tersebut. Namun, bukan perkara yang mudah bagi perusahaan dalam melakukan analisis terhadap kumpulan tweet dalam jumlah yang besar secara manual. Oleh sebab itu, dibutuhkan metode khusus yang dapat mengkategorisasi tweet ke dalam kelas positif, negatif, dan netral secara otomatis dengan menerapkan analisis sentimen.

Analisis sentimen merupakan bidang ilmu yang mempelajari cara untuk melakukan analisis terhadap opini, pendapat, dan penilaian dari suatu pihak terhadap objek tertentu yang dapat berupa layanan, produk, pihak, dan isu tertentu. Analisis sentimen dapat diimplementasikan pada beberapa level yang berbeda, baik itu teks yang berupa dokumen ataupun kalimat. Dalam melakukan analisis sentimen, terdapat beberapa algoritma yang dapat dimanfaatkan, salah satu diantaranya Support Vector Machine (SVM). Algoritma Support Vector Machine (SVM) merupakan algoritma yang telah digunakan dalam banyak bidang penelitian seperti face detection, bioinformatika, dan text mining [4]. Selain itu, algoritma ini juga memiliki tingkat accuracy yang lebih baik dalam proses klasifikasi teks daripada algoritma lainnya seperti K-Nearest Neighbors (KNN), C4.5 dan Nä̈ve Bayes [5].

Berdasarkan hal tersebut, penelitian ini akan menerapkan analisis sentimen pada opini publik terhadap maskapai penerbangan di Twitter menggunakan algoritma Support Vector Machine (SVM) untuk melakukan klasifikasi tweet ke dalam kelas positif, negatif, dan juga netral.

\section{LANDASAN TEORI}

\section{A. Twitter}

Twitter merupakan layanan social media micro blogging yang memberi keleluasaan bagi penggunanya dalam menyampaikan pesan berupa opini dan penilaian atas suatu isu atau persoalan [2]. Pesan yang disampaikan umumnya disebut dengan istilah tweet atau kicauan yang memiliki kapasitas maksimal 280 karakter teks.

\section{B. Analisis Sentimen}

Analisis sentimen atau opinion mining adalah pengaplikasian dari ilmu komputasi linguistik, text analysis, dan natural language processing yang digunakan untuk mengekstrak subjektifitas dari sebuah sumber teks [6]. Analisis sentimen sendiri kerap digunakan untuk menyatakan suka atau tidak suka terhadap suatu hal melalui sentimen positif dan negatif. Hal tersebut dapat dijadikan sebagai parameter untuk proses pengambilan keputusan.

\section{Text Mining}

Text Mining adalah proses penemuan informasi dan pengetahuan dari sebuah sumber berbentuk teks yang belum terlihat sebelumnya, dengan tujuan memperoleh pola untuk tujuan yang spesifik [7]. Dalam penerapannya, text mining kerap digunakan dalam melakukan analisis informasi dan merupakan alat dalam proses pengambilan keputusan dengan memanfaatkan data teks dengan jumlah banyak. Sebagai tahap awal, perlu dilakukan proses data preprocessing yang terdiri atas beberapa metode untuk membersihkan dan menstandarisasi data teks yang akan diolah. Beberapa metode tersebut diantaranya cleansing, case folding, tokenizing, filtering, dan stemming yang dijelaskan lebih lanjut sebagai berikut:

\section{Cleansing}

Cleansing adalah proses pembersihan data teks dari komponen yang tidak diperlukan atau dianggap sebagai noise. Komponen yang akan dihilangkan antara lain karakter HTML, simbol emoticon, hashtag (\#), username account (@username), retweet (RT), link URL, dan alamat website.

\section{Case Folding}

Case folding adalah proses standarisasi yaitu dengan mengubah seluruh elemen pada teks menjadi lowercase. Proses ini juga akan menghapus karakter selain huruf yang dianggap tidak berpengaruh terhadap proses pengolahan teks seperti angka dan tanda baca [8].

3. Tokenizing 
Tokenizing adalah proses dimana kumpulan kata yang terangkai dalam sebuah kalimat akan dipisah menjadi pecahan kata tunggal atau berbentuk token [8].

4. Filtering

Filtering adalah proses penghapusan kata-kata yang termasuk dalam kategori stopword atau kata-kata yang dianggap tidak memiliki peran untuk proses analisis sentimen. Untuk menunjang proses ini digunakan stopword list yang akan dicocokkan pada data teks yang ada [8].

5. Stemming

Stemming adalah proses transformasi kata-kata yang sebelumnya terdapat imbuhan menjadi bentuk kata dasarnya sesuai dengan struktur morfologinya. Maka dapat diasumsikan bahwa kata yang mengalami transformasi memiliki arti dan makna yang sama dengan kata dasarnya [9].

\section{Pembobotan TF-IDF}

TF-IDF (Term Frequency-Inverse Document Frequency) merupakan salah satu metode untuk melakukan pembobotan kata dari proses ekstraksi kata dengan menerapkan perhitungan kata umum di information retrival. Metode pembobotan ini merupakan penggabungan antara term frequency dan inverse document frequency. Term frequency merupakan jumlah kemunculan sebuah term pada sebuah dokumen. Besarnya jumlah term yang muncul berbanding lurus dengan pembobotan yang diberikan. Sedangkan inverse document frequency adalah proses untuk mengukur seberapa penting kata dalam suatu dokumen [10]. Nilai TF-IDF dapat diperoleh menggunakan persamaan (1), (2), dan (3).

$$
\begin{aligned}
& W_{t f_{t, d}}= \begin{cases}1+\log _{10} t f_{t, d}, & \text { if } t f_{t, d}>0 \\
0, & \text { if } t f_{t, d}=0\end{cases} \\
& i d f_{t}=\log _{10} \frac{N}{d f_{t}} \\
& W_{t, d}=W t f_{t, d} \cdot i d f_{t}
\end{aligned}
$$

Keterangan:

$W t f_{t, d}=$ Bobot kata di setiap dokumen

$t f_{t, d}=$ Jumlah kemunculan term dalam dokumen

$N \quad=$ Jumlah keseluruhan dokumen

Df = Jumlah dokumen yang mengandung term

idf = Bobot inverse dalam nilai $\mathrm{df}$

$W_{t, d}=$ Pembobotan TF-IDF

\section{E. Support Vector Machine (SVM)}

Support Vector Machine (SVM) merupakan satu di antara banyak algoritma yang digunakan untuk klasifikasi dan termasuk dalam kategori supervised learning. Konsep kerja Support Vector Machine yaitu dengan mencari hyperplane atau garis pembatas paling optimal yang berfungsi untuk memisahkan dua kelas [11]. Konsep kerja dari algoritma Support Vector Machine (SVM) dapat dilihat pada Gambar 1.
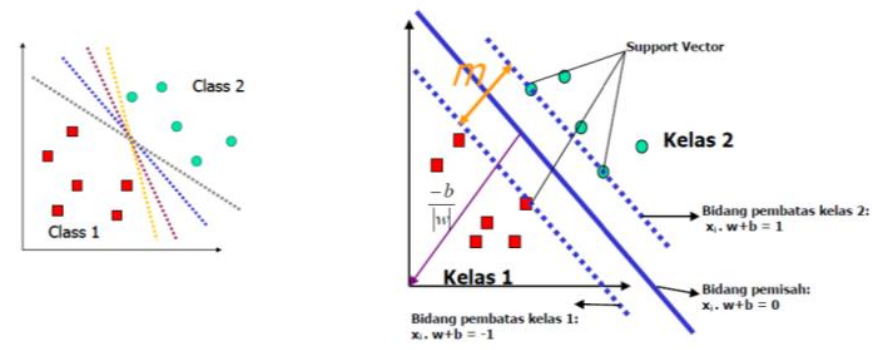

Gambar 1. Hyperplane Support Vector Machine [12]

Untuk memperoleh garis hyperplane yang paling optimal dalam memisahkan data ke dua buah kelas tersebut, maka digunakan perhitungan margin hyperplane dan menemukan titik maksimal. Dalam memperoleh hyperplane pada SVM, dapat menggunakan persamaan (4).

$\left(w \cdot x_{i}\right)+b=0$

Di dalam data $x_{i}$, yang termasuk pada kelas -1 dapat dirumuskan seperti pada persamaan (5).

$\left(w \cdot x_{i}+b\right) \leq 1, y_{i}=-1$

Sedangkan data $x_{i}$ yang termasuk pada kelas +1 dapat dirumuskan seperti pada persamaan (6).

$\left(w \cdot x_{i}+b\right) \geq 1, y_{i}=1$

Dalam proses klasifikasi dengan Support Vector Machine (SVM) biasanya ditemui kondisi dimana kernel linear bekerja tidak optimal yang mengakibatkan hasil klasifikasi terhadap data menjadi buruk. Hal tersebut dapat diatasi dengan menggunakan kernel non-linear dengan memanfaatkan kernel trick. Dengan memanfaatkan kernel trick, akan dilakukan mapping data input ke feature space yang dimensinya lebih tinggi sehingga membuat data input yang dihasilkan akan terpisah secara linear dan membentuk hyperplane yang optimal [13]. Persamaan dari setiap kernel SVM dapat dilihat pada Tabel 1.

Tabel 1. Persamaan Setiap Kernel SVM

\begin{tabular}{ll}
\hline \multicolumn{1}{c}{ Kernel } & \multicolumn{1}{c}{ Persamaan } \\
\hline Linear & $K\left(x_{i}, x\right)=x_{i}^{T} x$ \\
\hline Polynomial & $K\left(x_{i}, x\right)=\left(\gamma \cdot x_{i}^{T} x+r\right)^{p}, \gamma>0$ \\
\hline RBF & $K\left(x_{i}, x\right)=\exp \left(-\gamma\left|x_{i}-x\right|^{2}\right), \gamma>0$ \\
\hline Sigmoid & $K\left(x_{i}, x\right)=\tanh \left(\gamma x_{i}^{T} x+r\right)$ \\
\hline
\end{tabular}

\section{F. Confusion Matrix}

Confusion Matrix merupakan suatu instrumen yang digunakan untuk mengevaluasi performa dari model klasifikasi yang telah dihasilkan. Pada confusion matrix, hasil kelas prediksi akan dibandingkan dengan kelas data yang sebenarnya [14]. Hasil tersebut kemudian akan digunakan untuk menghitung nilai accuracy, precision, recall, dan $f$ score. Pengukuran evaluasi dengan confusion matrix dapat dilihat pada Tabel 2 . 
Tabel 2. Confusion Matrix

\begin{tabular}{cccc}
\hline \multirow{2}{*}{ Data } & \multicolumn{3}{c}{ Data Prediksi } \\
\cline { 2 - 4 } Aktual & TRUE & FALSE & TOTAL \\
\hline TRUE & TP & FN & P \\
\hline FALSE & FP & TN & N \\
\hline TOTAL & P' & N' & P+N \\
\hline
\end{tabular}

Keterangan:

$\mathrm{TP}($ True Positive $)=$ Data positif yang terklasifikasi secara benar,

$\mathrm{TN}($ True Negative $)=$ Data negatif yang terklasifikasi secara benar.

$\mathrm{FP}($ False Positive $)=$ Data negatif yang terklasifikasi menjadi positif.

FN $($ False Negative $)=$ Data positif yang terklasifikasi menjadi negatif.

\section{METODOLOGI PENELITIAN}

Dalam melakukan penelitian ini, setidaknya terbagi atas 3 tahapan besar, meliputi tahap awal, tahap pengembangan, dan tahap akhir. Setiap tahapan terdiri dari beberapa proses di dalamnya. Urutan tahapan secara lengkap dapat dilihat pada Gambar 2.

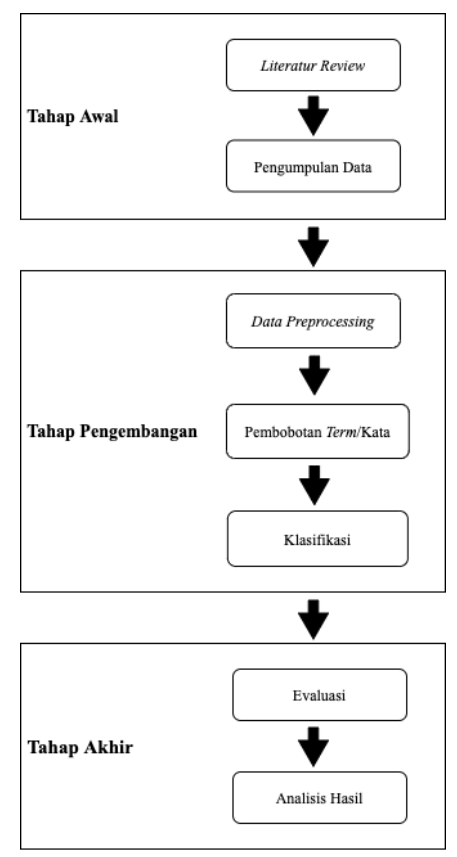

Gambar 2. Tahapan Penelitian

\section{A. Literatur Review}

Dalam proses ini dilakukan pencarian sumber literatur mengenai analisis sentimen yang mampu mendukung penelitian ini secara teoritis. Literatur yang diperoleh bersumber dari buku, skripsi terdahulu, jurnal, dan sumber pustaka dari internet.

\section{B. Pengumpulan Data}

Dataset yang digunakan pada penelitian ini adalah kumpulan opini berupa tweet terhadap beberapa perusahaan maskapai penerbangan di negara Amerika pada periode 17 Februari - 24 Februari 2015 yang diambil dari tautan dataset yang digunakan dalam penelitian ini bersumber dari https://www.figure-eight.com/data-for-everyone/. Seluruh data tweet dimuat dalam bentuk format CSV file.

\section{Data Preprocessing}

Sebelum masuk dalam proses klasifikasi, kumpulan data tweet harus melalui tahapan preprocessing untuk melakukan transformasi data yang awalnya berbentuk tidak terstruktur atau terdapat banyak noise, menjadi data yang terstruktur sehingga proses analisis menjadi lebih mudah. Beberapa metode yang akan diterapkan dalam proses data preprocessing dapat dilihat pada Gambar 3 .

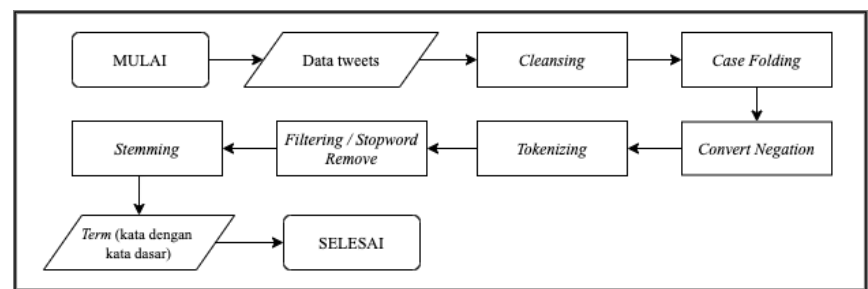

Gambar 3. Alur Proses Data Preprocessing

D. Pembobotan Term/Kata

Dalam proses ini, kumpulan term/kata akan divektorisasi atau diubah menjadi bentuk numerik. Hal tersebut perlu untuk dilakukan karena dalam klasifikasi hanya dapat memproses data dalam bentuk numerik saja. Proses pembobotan dalam penelitian ini menggunakan metode Term Frequency-Inverse Document Frequency (TF- IDF). Alur proses pembobotan dengan TF-IDF dapat dilihat pada Gambar 4.

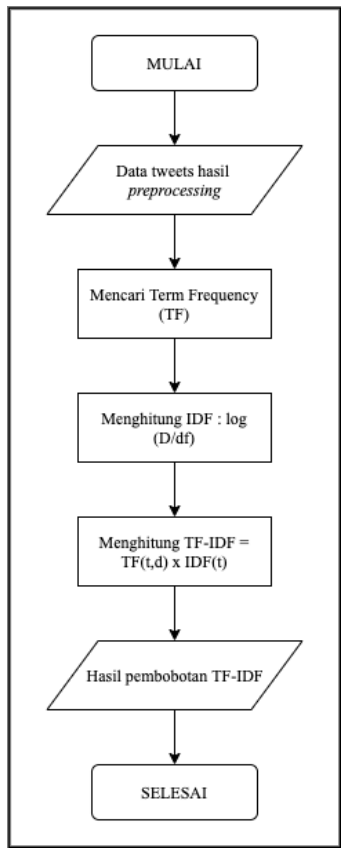

Gambar 4. Alur Proses Pembobotan TF-IDF 
E. Klasifikasi Support Vector Machine (SVM)

Dalam proses klasifikasi, digunakan algoritma Support Vector Machine (SVM) untuk mengenali pola pada data training yang telah diberi label dan kemudian menghasilkan machine learning model. Model yang dihasilkan selanjutnya digunakan untuk mengenali data tweet baru yang belum diberi label sehingga dihasilkan sebuah prediksi kelas sentimennya apakah itu positif, negatif, atau netral.

\section{F. Evaluasi}

Proses selanjutnya setelah melakukan klasifikasi yaitu dengan melakukan evaluasi untuk menguji performa model dari algoritma Support Vector Machine (SVM). Evaluasi dilakukan menggunakan instrumen bernama confusion matrix untuk mengukur nilai accuracy, precision, recall, dan $f$-score.

\section{G. Analisis Hasil}

Pada proses terakhir dalam penelitian ini, dilakukan analisis secara deskriptif terhadap hasil pengujian algoritma Support Vector Machine (SVM) untuk melakukan klasifikasi sentimen.

\section{IMPLEMENTASI DAN HASIL}

\section{A. Dataset}

Dataset yang digunakan dalam penelitian ini bersumber dari https://www.figure-eight.com/data-for-everyone/ yang merupakan platform penyedia dataset. Dataset tersebut merupakan kumpulan opini dari pengguna Twitter yang ditunjukkan kepada beberapa maskapai penerbangan di Amerika dalam kurun periode 17-24 Februari 2015.

Dalam menunjang proses pengujian yang akan dilakukan, diperlukan data untuk proses training dan testing. Hal tersebut dilakukan agar dapat menghasilkan machine learning model yang digunakan untuk memprediksi kelas pada data baru. Untuk itu, dilakukan proses sampling data sebanyak 2.000 data tweet dari dataset semula yang memiliki lebih dari 14.000 records data tweet. Proses selanjutnya adalah labelisasi data tweet yang dilakukan dengan memanfaatkan kamus lexicon yang bersumber dari tautan https://github.com/fnielsen/afinn/tree/master/afinn/data. Di dalam kamus lexicon yang digunakan, terdapat setidaknya lebih dari 3.000 kata umum dalam bahasa Inggris yang memiliki sentimen positif dan negatif beserta nilai bobotnya masing-masing.

Penentuan label suatu data tweet adalah berdasarkan nilai akumulasi secara keseluruhan kata. Jika suatu tweet memiliki nilai > 0 maka termasuk dalam kelas positif, jika nilai $<0$ maka termasuk dalam kelas negatif, dan jika nilai $=0$ maka termasuk dalam kelas netral. Suatu tweet dapat termasuk dalam kelas netral karena 2 hal yaitu tidak terdapat kata yang memiliki sentimen pada tweet sesuai dengan kamus lexicon, dan jumlah nilai kata bersentimen positif sama dengan kata bersentimen negatif.

Setelah proses labelisasi data tweet berdasarkan kamus lexicon, dilakukan langkah validasi dengan melakukan pengecekan hasil secara manual. Hal ini dilakukan karena ada

kemungkinan terdapat kata bersentimen pada data tweet yang tidak terdapat dalam kamus lexicon yang mengakibatkan hasil kelas atau label tidak sesuai.

Hasil dari proses labelisasi data tweet dapat dilihat pada Tabel 3.

Tabel 3. Hasil Labelisasi Data Tweet

\begin{tabular}{lr}
\hline Kelas Sentimen & \multicolumn{1}{c}{ Jumlah } \\
\hline Positif & 320 \\
\hline Negatif & 1257 \\
\hline Netral & 423 \\
\hline
\end{tabular}

Berdasarkan hasil labelisasi data tweet, terdapat ketidakseimbangan yang signifikan di antara 3 kelas. Kondisi tersebut jelas tidak ideal untuk dilakukan proses klasifikasi, sebab unbalanced dataset dapat membuat hasil prediksi dari machine learning model lebih cenderung pada data dengan kelas yang dominan. Untuk mengatasi kondisi tersebut, digunakan metode under sampling untuk menyeimbangkan jumlah data diantara tiga kelas sentimen dengan menyesuaikan pada kelas minoritas yaitu kelas sentimen positif. Hasil dari proses under sampling dapat dilihat pada Gambar 5.

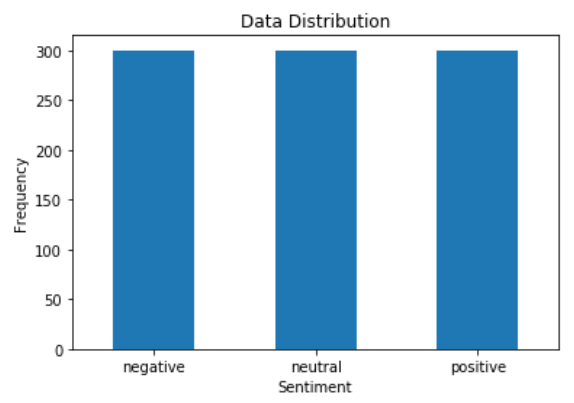

Gambar 5. Distribusi Data Hasil Under Sampling

\section{B. Data Preprocessing}

Kumpulan data tweet yang diproses dalam penelitian ini termasuk dalam unstructured text data. Maka dari itu perlu dilakukan data preprocessing untuk membersihkan dan menstandarisasi data tweet tersebut yang meliputi proses cleansing, case folding, convert negation, tokenizing, filtering, dan stemming. Hal tersebut dilakukan agar menghasilkan data yang proper untuk diolah dan membuat hasil klasifikasi menjadi optimal. Hasil implementasi proses tersebut dapat dilihat pada Tabel 4, 5, 6, 7, 8, dan 9 .

\section{Cleansing}

Tabel 4. Hasil Proses Cleansing

Sebelum Hasil

@United is truly the drunk uncle of boarding. Don't believe gate agent that overhead is full; don't reserve aisle http://t.co/cdZhTyd0aK is truly the drunk uncle of boarding. Do not believe gate agent that overhead is full; do not reserve aisle 


\section{Case Folding}

Tabel 5. Hasil Proses Case Folding

\section{Sebelum}

Hasil

is truly the drunk uncle of boarding. Do not believe gate agent that overhead is full; do not reserve aisle

is truly the drunk uncle of boarding do not believe gate agent that overhead is full do not reserve aisle

\section{Convert Negation}

Tabel 6. Hasil Proses Convert Negation

\section{Sebelum} Hasil

is truly the drunk uncle of boarding do not believe gate agent that overhead is full do not reserve aisle is truly the drunk uncle of boarding do notbelieve gate agent that overhead is full do notreserve aisle

\section{Tokenizing}

Tabel 7. Hasil Proses Tokenizing

\section{Sebelum}

is truly the drunk uncle of boarding do notbelieve gate agent that overhead is full do notreserve aisle

\section{Hasil}

['is', 'truly', 'the', 'drunk', 'uncle', 'of', 'boarding', 'do', 'notbelieve', 'gate', 'agent', 'that', 'overhead', 'is', 'full', 'do', 'notreserve', 'aisle']

\section{Filtering}

Tabel 8. Hasil Proses Filtering

\section{Sebelum}

['is', 'truly', 'the', 'drunk', 'uncle', 'of', 'boarding', 'do', 'notbelieve', 'gate', 'agent', 'that', 'overhead', 'is', 'full', 'do', 'notreserve', 'aisle']

\section{Hasil}

['truly', 'drunk', 'uncle', 'boarding', 'notbelieve', 'gate', 'agent', 'overhead', 'full', 'notreserve', 'aisle']

\section{Stemming}

Tabel 9. Hasil Proses Stemming

\begin{tabular}{ll}
\hline \multicolumn{1}{c}{ Sebelum } & \multicolumn{1}{c}{ Hasil } \\
\hline ['truly', 'drunk', 'uncle', & ['truli', 'drunk', 'uncl', \\
'boarding', 'notbelieve', & 'board', 'notbeliev', 'gate', \\
'gate', 'agent', 'overhead', & 'agent', 'overhead', 'full', \\
'full', 'notreserve', 'aisle'] & 'notreserv', 'aisl'] \\
\hline
\end{tabular}

\section{Pembobotan TF-IDF}

Pada proses ini, dilakukan perhitungan jumlah kemunculan tiap term pada keseluruhan data tweet (TF), menghitung jumlah tweet yang mengandung setiap term (DF), menghitung inverse dari nilai DF (IDF), dan mengkalikan nilai tf dan idf untuk memperoleh nilai bobot tiap tweet. Pross tersebut dilakukan menggunakan persamaan (1), (2), (3). Hasil pembobotan pada 3 sampel data tweet dapat dilihat pada Tabel 10.

Tabel 10. Hasil Pembobotan TF-IDF

\begin{tabular}{lrrrrrrrrr}
\hline \multirow{2}{*}{ Term } & \multicolumn{3}{c}{ TF } & & & & \multicolumn{3}{c}{ IDF } \\
\cline { 2 - 7 } & D1 & D2 & D3 & & IDF & D1 & D2 & D3 \\
\hline complet & 1 & 0 & 0 & 1 & 0,477 & 0,477 & 0 & 0 \\
\hline awesom & 2 & 0 & 0 & 1 & 0,477 & 0,954 & 0 & 0 \\
\hline experi & 1 & 0 & 1 & 2 & 0,176 & 0,176 & 0 & 0,176 \\
\hline last & 1 & 0 & 0 & 1 & 0,477 & 0,477 & 0 & 0 \\
\hline month & 1 & 0 & 0 & 1 & 0,477 & 0,477 & 0 & 0 \\
\hline thank & 1 & 0 & 0 & 1 & 0,477 & 0,477 & 0 & 0 \\
\hline flight & 1 & 0 & 0 & 1 & 0,477 & 0,477 & 0 & 0 \\
\hline depart & 1 & 0 & 0 & 1 & 0,477 & 0,477 & 0 & 0 \\
\hline time & 1 & 0 & 0 & 1 & 0,477 & 0,477 & 0 & 0 \\
\hline$\ldots$ & $\ldots$ & $\ldots$ & $\ldots$ & $\ldots$ & $\ldots$ & $\ldots$ & $\ldots$ & $\ldots$ \\
\hline travel & 0 & 0 & 1 & 1 & 0,477 & 0 & 0 & 0,477 \\
\hline meet & 0 & 0 & 1 & 1 & 0,477 & 0 & 0 & 0,477 \\
\hline & & & & & & & & \\
\hline
\end{tabular}

\section{Klasifikasi Support Vector Machine (SVM)}

Proses klasifikasi ditentukan ke dalam 3 kelas yaitu positif, negatif, dan netral menggunakan multi-class SVM one vs. one. Dataset kemudian dibagi menjadi training set dan testing set menggunakan dengan ratio 0,1 . Artinya $90 \%$ data digunakan untuk proses training, dan $10 \%$ digunakan untuk proses testing.

Algoritma Support Vector Machine (SVM) sendiri memiliki beberapa fungsi kernel dan parameter yang dapat digunakan ketika proses klasifikasi. Parameter yang digunakan dapat ditentukan nilainya dan perbedaan nilai pada parameter dapat mempengaruhi performa dari model. Untuk itu, dilakukan proses pengujian berupa parameter tunning pada setiap fungsi kernel sehingga menghasilkan machine learning model yang memiliki performa optimal.

Pengujian dilakukan dengan memberikan input nilai pada masing-masing parameter yang digunakan seperti degree, complexity, gamma, dan maximum iteration. Proses tersebut dilakukan pada setiap fungsi kernel dari algoritma Support Vector Machine (SVM) sesuai dengan parameter yang dimiliki. Detail dari pengujian tersebut dapat dilihat pada Tabel 11.

Tabel 11. Skenario Pengujian Support Vector Machine

\begin{tabular}{|c|c|c|}
\hline Kernel & Parameter & Nilai \\
\hline \multirow{2}{*}{ Linear } & Complexity $(C)$ & $\begin{array}{l}{[0,01 ; 0,1 ; 0,5 ; 1 ; 10 ; 20 ; 40 ;} \\
50 ; 100 ; 1000]\end{array}$ \\
\hline & $\begin{array}{l}\text { Maximum } \\
\text { Iteration }\end{array}$ & $\begin{array}{l}{[0,001 ; 0,01 ; 0,1 ; 1 ; 1,5 ; 2 ; 2,5 ;} \\
10 ; 20 ; 100]\end{array}$ \\
\hline \multirow{3}{*}{ Polynomial } & Degree $(d)$ & $\begin{array}{l}{[0,01 ; 0,1 ; 0,5 ; 1 ; 10 ; 20 ; 40 ;} \\
50 ; 100 ; 1000]\end{array}$ \\
\hline & Complexity $(C)$ & $\begin{array}{l}{[0,001 ; 0,01 ; 0,1 ; 1 ; 1,5 ; 2 ; 2,5 ;} \\
10 ; 20 ; 100]\end{array}$ \\
\hline & $\operatorname{Gamma}(\gamma)$ & $\begin{array}{l}{[0,01 ; 0,1 ; 0,5 ; 1 ; 10 ; 20 ; 40 ;} \\
50 ; 100 ; 1000]\end{array}$ \\
\hline
\end{tabular}




\begin{tabular}{lll}
\hline \multirow{3}{*}{ RBF } & Complexity $(C)$ & $\begin{array}{l}{[0,001 ; 0,01 ; 0,1 ; 1 ; 1,5 ; 2 ; 2,5 ;} \\
10 ; 20 ; 100]\end{array}$ \\
\cline { 2 - 3 } & Gamma $(\gamma)$ & $\begin{array}{l}{[0,01 ; 0,1 ; 0,5 ; 1 ; 10 ; 20 ; 40 ;} \\
50 ; 100 ; 1000]\end{array}$ \\
\hline \multirow{3}{*}{ Sigmoid } & Complexity $(C)$ & $\begin{array}{l}{[0,001 ; 0,01 ; 0,1 ; 1 ; 1,5 ; 2 ; 2,5 ;} \\
10 ; 20 ; 100]\end{array}$ \\
\cline { 2 - 3 } & Gamma $(\gamma)$ & $\begin{array}{l}{[0,01 ; 0,1 ; 0,5 ; 1 ; 10 ; 20 ; 40 ;} \\
50 ; 100 ; 1000]\end{array}$ \\
\hline
\end{tabular}

E. Hasil Pengujian Algoritma SVM

Proses pengujian dilakukan untuk menghasilkan machine learning model dengan performa yang paling optimal melalui evaluasi menggunakan confusion matrix.

\section{Kernel Linear}

Pada kernel linear, dilakukan pengujian terhadap parameter complexity dan maximum iteration. Dengan menggunakan nilai parameter complexity antara 0,01 hingga 1.000, nilai testing accuracy terus mengalami peningkatan hingga mencapai yang terbaik pada nilai complexity $=10$, yaitu sebesar $83,33 \%$. Nilai complexity yang semakin besar, menyebabkan nilai accuracy cenderung mengalami penurunan. Setelah itu dengan menggunakan nilai parameter max iteration antara 10 hingga 1.000 dan complexity $=10$, nilai testing accuracy terus mengalami peningkatan hingga mencapai yang terbaik pada nilai max iteration $=250$, yaitu sebesar $83,33 \%$. Nilai accuracy juga tetap konstan pada nilai max iteration yang lebih besar.

Hasil confusion matrix dari penggunaan nilai complexity $=$ 10 dan maximun iteration $=250$ pada kernel linear dapat dilihat pada Gambar Tabel 12.

Tabel 12. Confusion Matrix Kernel Linear

\begin{tabular}{crrr}
\hline \multirow{2}{*}{ Aktual } & \multicolumn{3}{c}{ Prediksi } \\
\cline { 2 - 4 } & Negatif & Netral & Positif \\
\hline Negatif & 25 & 2 & 3 \\
\hline Netral & 6 & 29 & 1 \\
\hline Positif & 2 & 1 & 26 \\
\hline
\end{tabular}

Dari confusion matrix tersebut, juga dilakukan perhitungan precision, recall, dan $f$-score sebagai berikut:

\section{Precision}

Positif $=\frac{26}{26+2+2}=0,87 \quad \mid$ Netral $=\frac{29}{29+6+1}=0,81 \mid$

Negatif $=\frac{25}{25+6+2}=0,83$

Average Recall $=\frac{0,87+0,81+0,83}{3} \times 100 \%=83,67 \%$

Recall

Positif $=\frac{26}{26+3+1}=0,87 \quad \mid$ Netral $=\frac{29}{29+2+2}=0,88 \mid$ Negatif $=\frac{25}{25+6+2}=0,76$

Average Precision $=\frac{0,87+0,88+0,76}{3} \times 100 \%=83,67 \%$

$\boldsymbol{F}$-score $=\frac{2 \times 83,67 \times 83,67}{83,67+83,67}=83,67 \%$

\section{Kernel Polynomial}

Pada kernel polynomial, dilakukan pengujian terhadap parameter complexity, gamma, dan degree. Dengan menggunakan nilai parameter complexity antara 0,01 hingga
1.000, nilai testing accuracy terus mengalami peningkatan hingga mencapai yang terbaik pada nilai complexity $=10$, yaitu sebesar 76,04\%. Nilai complexity yang semakin besar, menyebabkan nilai accuracy cenderung mengalami penurunan. Setelah itu, dengan menggunakan nilai parameter gamma antara 0,001 hingga 100 dan complexity $=10$, nilai testing accuracy mencapai yang terbaik pada nilai gamma $=1$ yaitu sebesar $76,04 \%$. Nilai gamma yang semakin besar juga menyebabkan nilai accuracy mengalami penurunan. Terakhir, dengan menggunakan nilai parameter degree antara 1 hingga 4 , complexity $=10$, dan gamma $=1$, nilai testing accuracy mencapai yang tertinggi pada nilai degree $=1$ yaitu sebesar $83,33 \%$.

Hasil confusion matrix dari penggunaan nilai complexity $=10$, gamma $=1$, dan degree $=1$ pada kernel polynomial dapat dilihat pada Tabel 13 .

\section{Tabel 13. Confusion Matrix Kernel Polynomial}

\begin{tabular}{crrr}
\hline \multirow{2}{*}{ Aktual } & \multicolumn{3}{c}{ Prediksi } \\
\cline { 2 - 4 } & Negatif & Netral & Positif \\
\hline Negatif & 25 & 2 & 3 \\
\hline Netral & 6 & 29 & 1 \\
\hline Positif & 2 & 1 & 26 \\
\hline
\end{tabular}

Dari confusion matrix tersebut, juga dilakukan perhitungan precision, recall, dan $f$-score sebagai berikut:

\section{Precision}

Positif $=\frac{26}{26+2+2}=0,87 \mid$ Netral $=\frac{29}{29+6+1}=0,81 \mid$

Negatif $=\frac{25}{25+6+2}=0,83$

Average Recall $=\frac{0,87+0,81+0,83}{3} \times 100 \%=83,67 \%$

Recall

Positif $=\frac{26}{26+3+1}=0,87 \mid$ Netral $=\frac{29}{29+2+2}=0,88 \mid$

Negatif $=\frac{25}{25+6+2}=0,76$

Average Precision $=\frac{0,87+0,88+0,76}{3} \times 100 \%=83,67 \%$

F-score $=\frac{2 \times 83,67 \times 83,67}{83,67+83,67}=83,67 \%$

\section{Kernel RBF}

Pada kernel $R B F$, dilakukan pengujian terhadap parameter complexity dan gamma. Dengan menggunakan nilai parameter complexity antara 0,01 hingga 1.000 , nilai testing accuracy terus mengalami peningkatan hingga mencapai yang terbaik pada nilai complexity $=10$ yaitu sebesar $84,37 \%$. Dengan nilai complexity yang lebih besar, nilai accuracy yang dihasilkan tetap konstan. Setelah itu, dengan menggunakan nilai parameter gamma antara 0,001 hingga 100 dan complexity $=10$, nilai testing accuracy terus mengalami peningkatan hingga mencapai yang terbaik pada nilai gamma $=1$, yaitu sebesar $84,37 \%$. Nilai gamma yang semakin besar, menyebabakan nilai accuracy yang dihasilkan cenderung mengalami penurunan.

Hasil confusion matrix dari penggunaan nilai complexity $=10$, gamma $=1$ pada kernel $R B F$ dapat dilihat pada Tabel 14. 
Tabel 14. Confusion Matrix Kernel RBF

\begin{tabular}{crrr}
\hline \multirow{2}{*}{ Aktual } & \multicolumn{3}{c}{ Prediksi } \\
\cline { 2 - 4 } & Negatif & Netral & Positif \\
\hline Negatif & 26 & 3 & 2 \\
\hline Netral & 5 & 28 & 1 \\
\hline Positif & 2 & 2 & 27 \\
\hline
\end{tabular}

Dari confusion matrix tersebut, juga dilakukan perhitungan precision, recall, dan $f$-score sebagai berikut:

\section{Precision}

Positif $=\frac{27}{27+2+2}=0,87 \quad \mid$ Netral $=\frac{28}{28+5+1}=0,82 \mid$

Negatif $=\frac{26}{26+3+2}=0,84$

Average Recall $=\frac{0,87+0,82+0,84}{3} \times 100 \%=84,33 \%$

\section{Recall}

Positif $=\frac{27}{27+1+2}=0,90 \mid$ Netral $=\frac{28}{28+3+2}=0,85 \mid$ Negatif $=\frac{26}{26+5+2}=0,79$

Average Precision $=\frac{0,90+0,85+0,79}{3} \times 100 \%=84,67 \%$

F-score $=\frac{2 \times 84,67 \times 84,33}{84,67+84,33}=84,50 \%$

\section{Kernel Sigmoid}

Pada kernel sigmoid, juga dilakukan pengujian terhadap parameter complexity dan gamma. Dengan menggunakan nilai parameter complexity antara 0,01 hingga 1.000 , nilai testing accuracy terus mengalami peningkatan hingga mencapai yang terbaik pada nilai complexity $=10$ yaitu sebesar $80,20 \%$. Nilai complexity yang semakin besar menyebabkan nilai accuracy yang dihasilkan cenderung mengalami penurunan. Setelah itu, dengan menggunakan nilai parameter gamma antara 0,001 hingga 100 dan complexity $=$ 10, nilai testing accuracy terus mengalami peningkatan hingga mencapai yang terbaik pada nilai gamma $=0,1$ yaitu sebesar 82,29\%. Nilai gamma yang semakin besar juga menyebabkan nilai accuracy yang dihasilkan mengalami penurunan.

Hasil confusion matrix dari penggunaan nilai complexity $=$ 10, gamma $=0,1$ pada kernel sigmoid dapat dilihat pada Tabel 15.

Tabel 15. Confusion Matrix Kernel Sigmoid

\begin{tabular}{crrr}
\hline \multirow{2}{*}{ Aktual } & \multicolumn{3}{c}{ Prediksi } \\
\cline { 2 - 4 } & Negatif & Netral & Positif \\
\hline Negatif & 26 & 2 & 2 \\
\hline Netral & 5 & 27 & 2 \\
\hline Positif & 2 & 4 & 26 \\
\hline
\end{tabular}

Dari confusion matrix tersebut, juga dilakukan perhitungan precision, recall, dan $f$-score sebagai berikut:

\section{Precision}

Positif $=\frac{26}{26+2+4}=0,81 \mid$ Netral $=\frac{27}{27+5+2}=0,79 \mid$ Negatif $=\frac{26}{26+2+2}=0,87$
Average Recall $=\frac{0,81+0,79+0,87}{3} \times 100 \%=82,33 \%$

Recall

Positif $=\frac{26}{26+2+2}=0,87 \quad \mid$ Netral $=\frac{27}{27+2+4}=0,82 \mid$

Negatif $=\frac{26}{26+5+2}=0,79$

Average Precision $=\frac{0,87+0,82+0,79}{3} \times 100 \%=82,67 \%$

$\boldsymbol{F}$-score $=\frac{2 \times 82,67 \times 82,33}{82,67+82,33}=82,50 \%$

5. Rangkuman Pengujian Algoritma SVM

Berdasarkan pada pengujian yang telah dilakukan, dihasilkan model dengan nilai performa terbaik pada setiap fungsi kernel. Rangkuman dari hasil pengujian dapat dilihat pada Tabel 16.

Tabel 16. Rangkuman Hasil Pengujian

\begin{tabular}{|c|c|c|c|c|c|}
\hline Kernel & Parameter & Acc. & Prec. & Rec. & $\begin{array}{c}\text { F- } \\
\text { score }\end{array}$ \\
\hline Linear & $\begin{array}{l}\text { complexity = } \\
10, \text { max } \\
\text { iteration }= \\
250\end{array}$ & $83,33 \%$ & $83,67 \%$ & $83,67 \%$ & $83,67 \%$ \\
\hline Polynomial & $\begin{array}{l}\text { complexity }= \\
10, \text { gamma }= \\
1, \text { degree }=1\end{array}$ & $83,33 \%$ & $83,67 \%$ & $83,67 \%$ & $83,67 \%$ \\
\hline $\mathrm{RBF}$ & $\begin{array}{l}\text { complexity }= \\
10, \text { gamma }= \\
1\end{array}$ & $84,37 \%$ & $84,33 \%$ & $84,67 \%$ & $84,50 \%$ \\
\hline Sigmoid & $\begin{array}{l}\text { complexity }= \\
10, \text { gamma }= \\
0.1\end{array}$ & $82,29 \%$ & $82,33 \%$ & $82,67 \%$ & $82,50 \%$ \\
\hline
\end{tabular}

Hasil secara keseluruhan menunjukkan kernel RBF menghasilkan nilai accuracy yang terbaik. Penggunaan kernel RBF dengan parameter complexity $=10$ dan gamma $=1$ mampu menghasilkan nilai accuracy sebesar 84,37 \%. Selain accuracy, kernel RBF juga menghasilkan nilai precision, recall, dan $f$-score yang terbaik dengan penggunaan nilai parameter yang sama.

\section{F. Hasil Pengujian Cross Validation}

Untuk melakukan validasi tingkat accuracy dari suatu model, maka dilakukan pengujian dengan metode 10-fold cross validation. Pengujian ini menggunakan fungsi kernel RBF dengan nilai parameter complexity $=10$ dan gamma $=1$ yang pada proses parameter tuning menghasilkan nilai accuracy, precision, recall, dan f-score terbaik. Hasil dari 10fold cross validation dapat dilihat pada Gambar 6.

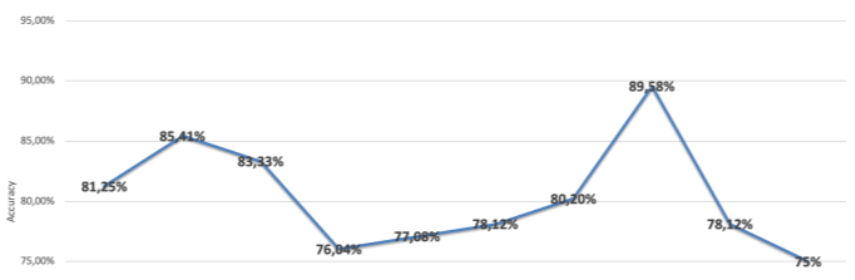

Gambar 6. Hasil 10-fold Cross Validation 


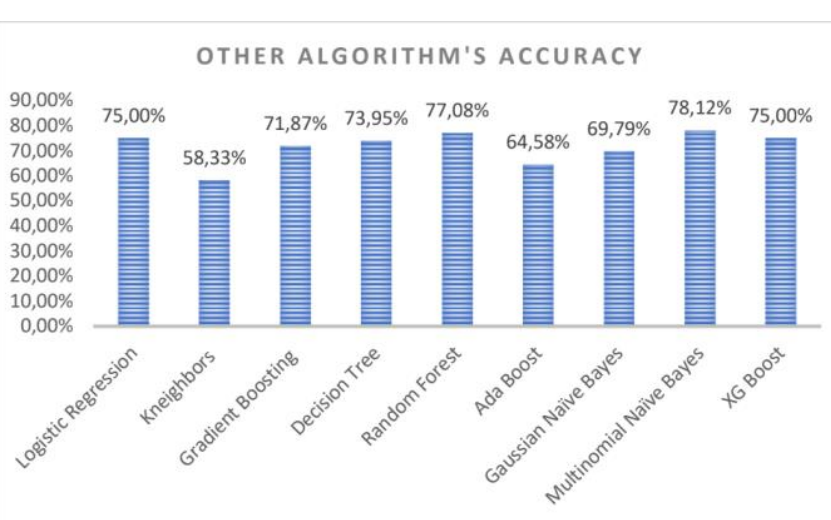

Gambar 7. Grafik Perbandingan Accuracy Algoritma Lain.

Dari 10 kali eksperimen pengujian yang dilakukan, diperoleh nilai accuracy yang beragam dan diperoleh rata-rata accuracy sebesar $80,41 \%$ dan bisa terlihat hasil tersebut lebih baik dari accuracy algoritma yang lain, dimana pada algoritma yang accuracy terbaik diraih oleh Multinominal Naïve Bayes dengan $78.21 \%$.

\section{KESIMPULAN}

Berdasarkan dari penelitian yang telah dilakukan, dapat disimpulkan bahwa algoritma Support Vector Machine (SVM) terbukti mampu diterapkan dengan baik untuk melakukan analisis 26entiment dengan didukung oleh beberapa metode preprocessing, pembobotan term menggunakan TF-IDF, dan parameter tuning algoritma. Selain itu, pada proses pengujian algoritma Support Vector Machine (parameter tuning), nilai accuracy terbaik dihasilkan oleh kernel RBF dengan nilai parameter complexity $=10$ dan gamma $=1$, yaitu sebesar 84,37\%. Sedangkan pada pengujian menggunakan 10-fold cross validation, diperoleh rata-rata nilai accuracy sebesar $80,41 \%$. Nilai precision, recall, dan $f$-score terbaik juga dihasilkan oleh kernel $\mathrm{RBF}$ dengan nilai parameter complexity $=10$ dan gamma $=1$, yang masing-masing sebesar $84,33 \%, 84,67 \%$, dan $84,50 \%$.

\section{REFERENSI}

[1] FAA. (2017). Federal Aviation Administration's Air Traffic by the Numbers. Diakses dari: https://www.transtats.bts.gov/airports.asp

[2] Zephoria. (2019). Top 10 Twitter Statistics - Updated October 2019. Diakses dari: https://zephoria.com/twitter-statistics-top- ten/

[3] Hamdan, H., Bellot, P. \& Bechet, F. (2015). Lsislif: Feature Extraction and Label Weighting for Sentiment Analysis in Twitter. Proceedings of International
Workshop on Semantic Evaluation (SemEval-2015), pp. 568.

[4] Rainarli, E. \& Romadhan, A. (2017). Perbandingan Simple Logistic Classifier Dengan Support Vector Machine Dalam Memprediksi Kemenangan Atlet. Journal of Information Systems Engineering and Business Intelligence, pp. 87-91.

[5] Malheiro, R., Panda, R., Gomes, P. \& Paiva, R. P. (2013). Music Emotion Recognition from Lyrics: A Comparative Study. International Workshop on Machine Learning and Music.

[6] Barawi, M.H. \& Seng, Y.Y. (2013). Evaluation of Resources Creations by Using Sentiment Analysis. International Conference on Cognitive Science. Elsevier Publisher Inc.

[7] Mustafa, A., Akbar, A. \& Sultan, A. (2009). Knowledge Discovery Using Text Mining: A Programmable Implementation on Information Extraction and Categorization. International Journal of Multimedia and Ubiquitos Engineering, Vol. 4(2), April.

[8] Vijayarani, S., Ilamathi, J. \& Nithya. (2015). Preprocessing Techniques for Text Mining - An Overview. International Journal of Computer Science \& Communication Networks, Vol. 5(1), pp. 7-16.

[9] Indriati \& Ridok A. (2016). Sentiment Analysis For Review Mobile Application Using Neighbor Method Weighted K-Nearest Neighbor (NWKNN). Journal of Environmental Engineering \& Sustainable Technology, Vol. 03(01), July 2016, pp. 23-32.

[10] Akbari, M.I.H.A.D., Novianty, A. \& Setianingsih, C. (2012). Analisis Sentimen Menggunakan Metode Learning Vector Quantization. e-Proceeding of Engineering, Vol. 4(2), Agustus 2017, pp. 2283-2292.

[11] Lidya, S.K., Sitompul, O.S. \& Efendi, S. (2015). Sentiment Analysis Pada Teks Bahasa Indonesia Menggunakan Support Vector Machine (SVM) dan KNearest Neighbor (K- NN). Seminar Nasional Teknologi Informasi dan Komunikasi.

[12] Sembiring, K. (2007). Penerapan Teknik Support Vector Machine Untuk Pendeteksian Intrusi Pada Jaringan [Skripsi]. Program Studi Teknik Informatika, Institut Teknologi Bandung.

[13] Shandra, E.N., Setiawan B.D., Sari Y.A. (2019). Klasifikasi Pola Sidik Bibir untuk Menentukan Jenis Kelamin Manusia dengan Metode Gray Level CoOccurrence Matrix dan Support Vector Machine. Jurnal Pengembangan Teknologi Informasi dan Ilmu Komputer, Vol. 3(3), pp. 2753-2760.

[14] Salekhah, C.I. (2016). Implementasi Metode Multi Class Support Vector Machine Untuk Klasifikasi Emosi pada Lirik Lagu Bahasa Indonesia. Universitas Komputer Indonesia (Unikom). 